\title{
Climate and Water Resources Variation in Afghanistan and the Need for Urgent Adaptation Measures
}

\author{
M. Najim. Nasimi $^{1^{*}}$, Jay Sagin ${ }^{2}$, N. T. S. Wijesekera ${ }^{3}$ \\ ${ }^{1}$ Lecturer, Kabul Polytechnic University, Afghanistan \\ ${ }^{2}$ Professor, Nazarbayev University, Kazakhstan \\ ${ }^{3}$ Senior Professor, University of Moratuwa, Sri Lanka
}

How to cite this paper: Nasimi, M. N., Sagin, J., Wijesekera, N. T. S. (2020) Climate and Water Resources Variation in Afghanistan and the Need for Urgent Adaptation Measures. International Journal of Food Science and Agriculture, 4(1), 49-64.

DOI: $10.26855 /$ ijfsa.2020.03.009

Received: January 28, 2020

Accepted: February 17, 2020

Published: March 5, 2020

*Corresponding author: M. Najim. Nasimi, Lecturer, Kabul Polytechnic University, Afghanistan.

Email: najim.nasimi@kpu.edu.af

\begin{abstract}
Climate changes due to anthropogenic distortions to the environment are increasing worldwide, and also throughout Afghanistan. Effects on Water resources reflected by the intensification of floods and droughts cause emergency situations in Afghanistan. In this research, we have reviewed the changes of climate factors and their impact on the water resources in Afghanistan. Meteorological data, including temperature, precipitation, streamflow data, glacier monitoring data were collected and used to analyze the changes reflected in precipitation, surface water, glacier melting, and groundwater resource. Temperatures of winter seasons in one decade starting from 2007 to 2017 had increased from $0.9^{\circ} \mathrm{C}$ to $2.5^{\circ} \mathrm{C}$. The summer season temperature had increased from $0.5{ }^{\circ} \mathrm{C}$ to $1.2{ }^{\circ} \mathrm{C}$. These show that the winter periods are getting warmer when compared to the temperature of the summer periods. Glacier volumes have decreased by $18.53 \%$ between 1994 to 2015 . Surface runoff in streams have dramatically reduced by $22 \%$ when compared with the that observed between 1962 to 2017. It was identified that the streamflow peaks become sharper and reach larger values. Due these floods have a rapid response with a larger destructive power. The prolonged droughts also show a devastating characteristic. Due to the changes in the climate groundwater resources are depleting and has been worst hit due to over extractions. The Karez system, which is the local underground water channeling network has been abandoned and dried up all over Afghanistan. Thus, sustainable climate change adaptation programs are urgently required to be developed and implemented in Afghanistan.
\end{abstract}

\section{Keywords}

Afghanistan glaciers, Afghanistan river basins, Afghanistan temperature, Afghanistan precipitation

\section{Introduction}

Afghanistan is a land locked country located in Central Asia (CA) and has a continental dry climate. The primary sources of livelihood for the local people are agriculture and livestock. Soil productivity and sufficient water resources are very important, so the reliance on the natural rainfall, snow, groundwater, and glaciers in great. Climate change impacts much of the water distribution with an increase in emergency disaster events worldwide [1]. The Second Assessment of the Intergovernmental Panel on Climate Change (IPCC) states that an increasing concentration of greenhouse gases in the atmosphere is likely to cause an increase in the global average temperature between 1 and 3.5 ${ }^{\circ} \mathrm{C}$ over the forthcoming century [20]. This will lead to a more vigorous hydrological cycle, with changes in precipitation and evapotranspiration rates regionally. Nearly all regions of the world are expected to experience a net negative impact 
of climate change on water resources and freshwater ecosystems [3]. It is thought that climate change will threaten the lives and livelihood of millions of people through increasing the frequency of floods and droughts; declining the crop yield, which will also increase the risk of poverty and hunger [4]. A number of sources indicate that during the past years, Afghan people have been suffering from the serious effect of sudden floods and droughts [5]. The changes in the runoff volume and pattern of the river regimes have been directly reliant on the increase of the temperature that Afghanistan has experienced in the last decades. Many studies suggest that relatively small changes in temperature and precipitation can have significant effects on runoff. With no change in precipitation, estimated runoff has declined by $3 \%$ to $12 \%$ with a $2{ }^{\circ} \mathrm{C}$ increase in temperature and by $7 \%$ to $21 \%$ with a $4{ }^{\circ} \mathrm{C}$ increase in temperature [6]. The Afghanistan water system is highly dependent on snow precipitation. Simulation studies suggest that relatively small changes in temperature and precipitation can have significant effects on runoff, especially in semiarid areas [6].

Worldwide, many climates change modeling research have been developed with estimations of the future climate change scenarios. Such modeling requires a broad survey using historical data to investigate the extent of its impact. One study of Southern Taiwan, shows that the runoff has raised during the wet season and declined during the dry season [7]. Another study in China which reviewed the impact of climate change on water resources and agriculture related to the historical analyses of temperature, precipitation, evapotranspiration, runoff, and glaciers. The study indicates that precipitation has increased in the south and northwest of the country; in contrast, the northeastern part has suffered from drought due to a decline in precipitation [8].

Few studies related to the climate change were conducted in Afghanistan because of a lack of consistent databases and information about the climate change impact on water resources. A review of historical trends of rainfall, groundswells, glaciers, stream flow, and snowpack will be helpful for implementing local applications. This review research will help scientific communities, water resources organizations and the government of Afghanistan to have overall information about the current water resource conditions and to support future water resources planning and management.

\section{Background studies}

The Central South Asia region, which includes Afghanistan, Nepal, Bangladesh and Pakistan, is considered to be one of the worst affected regions from global warming. Climate change has significantly affected the agriculture sectors across Central South Asian countries through increased incidences of extreme events such as floods, droughts, cyclones, and storms [9,10]. Afghanistan in one country that has experienced intensive flood and drought disaster emergencies [11]. Also, recurrent drought cycles that lower water tables and cause large rivers to run dry for at least part of the year have occurred in Afghanistan [12]. The climate-induced extreme weather is quite significant, which is compounded by their relatively high vulnerability and lower adaptive capacity for large-scale implementation for adaptation activities [13]. A study using the indicators of the Fragile States Index (FSI) conclude that climate does affect the fragility in Afghanistan turning destabilized governments into fragile states and is likely to ruin the social structures [14]. The vulnerability index analysis in Afghanistan using the FSI indicates that humanitarian disasters lead to unrest and conflicts [15]. As well, the overwhelming number of natural disasters such as earthquakes, floods, and droughts in Afghanistan coupled with mounting concern for the adverse effect of climate change will induce displacement and human migration [16].

In addition, Afghanistan is among the countries which lack knowledge of climate change and water cycle distortion concepts since less than $30 \%$ of the people are aware of related research work and prediction analysis [17]. At the same time, local communities through the connection chain of generation communications have indicated dramatic environmental changes [18]. Local communities in northeastern region (Badakhshan province) shared that they observed changes in the weather condition; summer is getting cold in the lower areas and hotter in the upper areas as compared to 10 years ago. These changes have delayed the agriculture harvesting. They witnessed speedy winds during summer and changes in the rain pattern, with less rain as compared to 10 years ago during the rainy season of March and April [19].

Glaciers are mostly located in the North East region of Afghanistan and studies in the Wakhan corridor suggest that many glaciers exhibit retreat and the frequency and size of the valley-basin lakes have increased as a result of melting snow and ice in this region [20]. In the Kabul River Basin (KRB), an analysis for change in Land Use and Land Cover (LULC) between 2001 to 2010 indicates an increase of the cropland by 13\%, grassland by $11 \%$, water bodies by $18 \%$ and built-up land by $4 \%$. At the same time, there was a decrease of the forest by $25 \%$, pasture by $7 \%$ and snow/ice covered areas by $3 \%$. This data illustrates the climate change and human distortions of the region [21]. Field surveys show that farmers understand climate change more deeply. Farmers are working on adaptation strategies by planting trees and changing the crop type and crop calendars [22]. The Afghanistan government has introduced a climate change adaptation policy program, but Afghanistan local people lack the capacity to work on the actual adaptation 
and application of this program. The proper promotion and support for this program is required [11]. Flora and fauna in Afghanistan are under intensive pressure also. As an example, the snow leopard habitat in the highest mountain is under pressure. An IPCC scenario estimates the distribution of the snow leopard habitat will be dramatically decreased to $58 \%$ by 2080 in the Hindukush-Pamir mountain range of Afghanistan [23]. For addressing the issues of adaptation, mitigation, and integration of climate change into national planning program, the National Adaptation Program of Action (NAPA) for climate change was adopted in 2009 in Afghanistan, but still it is missing any real practical application and implementation [24].

\section{Methods and Materials}

\subsection{Data and Data checking}

In this research works, the available meteorological data, including temperature, precipitation, glaciers, and stream flow discharge gages data have been collected from the Meteorological department and Ministry of Energy and Water (MEW) of Afghanistan. Due to war, Afghanistan is missing data from 1978 till 2007. For the current study, the meteorological data, was collected from the eight provinces, including Bamyan, Kabul, Badakhshan, Laghman, Helmand, Balkh, Sheberghan and Takhar which are located in five river basins. The data was collected from 2007 till 2017. The meteorological precipitation data of the five river basins of Afghanistan was obtained from the MEW for the same period of time. Stream flow discharge gages data was collected from 1962 to 1978 and from 2007 to 2017 from the same ministry. The data gap of more than 29 years is due to the war in Afghanistan. The glaciers data was collected from the ICIMOD local office of Afghanistan. Also, the groundwater wells data was collected from the Ministry of Mines and Petroleum in Kabul.

\subsection{Study area}

Afghanistan has five river basins which are Helmand, Amu Darya, Hurrirud Murghab, Kabul and North river basins. These river basins are the basis for this research on the effect of climate change (Figure 1).

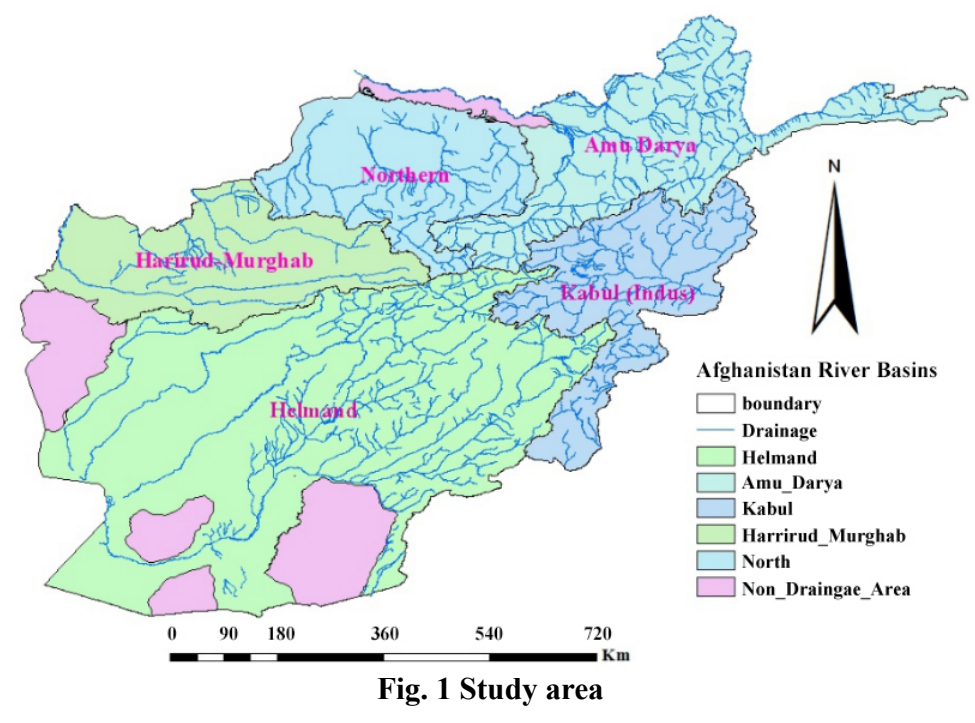

\subsection{Methodology}

The method used in this study is relying on changes of the historical climate and water resources shown in the chart below (see Figure 2) consist of four stages. The GIS, statistical methods and field surveys are the main tools and approaches used for analysis of the data. First stage, changes on the historical trend of temperature as a leading indicator of climate changes, was investigated. The temperature changes in trend patterns were investigated separately for both winter and summer seasons from the available observed data. In the second stage, changes on water resources including precipitation, glaciers and groundwater were studied. These changes will show the differences upon the increases or decreases of the mentioned water resources components. In the third stage, changes of the stream flow from the discharge station gauges were investigated. This investigation is based on studying the changes on the peak, shifting of peak, increasing or reducing the volume of water. In the final stage some adaptation measures upon the economic and social statues of Afghanistan are recommended. 
Stage 1: Changes on Climate Factor

\section{Temperature}

Stage 2: Water Resources Changes

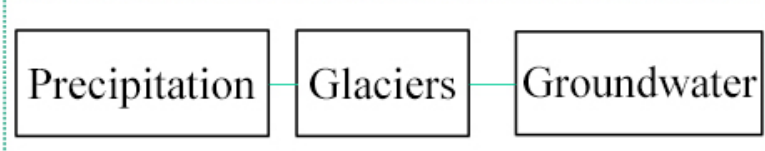

Stage 3: Impact on Surface water

\section{Streamflow}

\section{Stage 4: Solutions}

\section{Adaption Measures}

Fig. 2 Methodology flow chart

\section{Results}

Each component of the temperature and water resources including temperature, precipitation, glaciers, groundwater, stream flow were analyzed separately using the statistical method. The findings are presented for each separately.

\subsection{Temperature}

Temperature changes were investigated separately for summer and winter seasons, 2007-2017 years. The temperature changes in summer seasons varied from 0.5 to $1.2{ }^{\circ} \mathrm{C}$ in the ten years across all Afghanistan, from 2007 to 2017 , as shown in Figure 3. Similarly, the variation of temperature in the winter seasons was between 0.9 to $2.6^{\circ} \mathrm{C}$ in the same ten years, as shown in Figure 4.

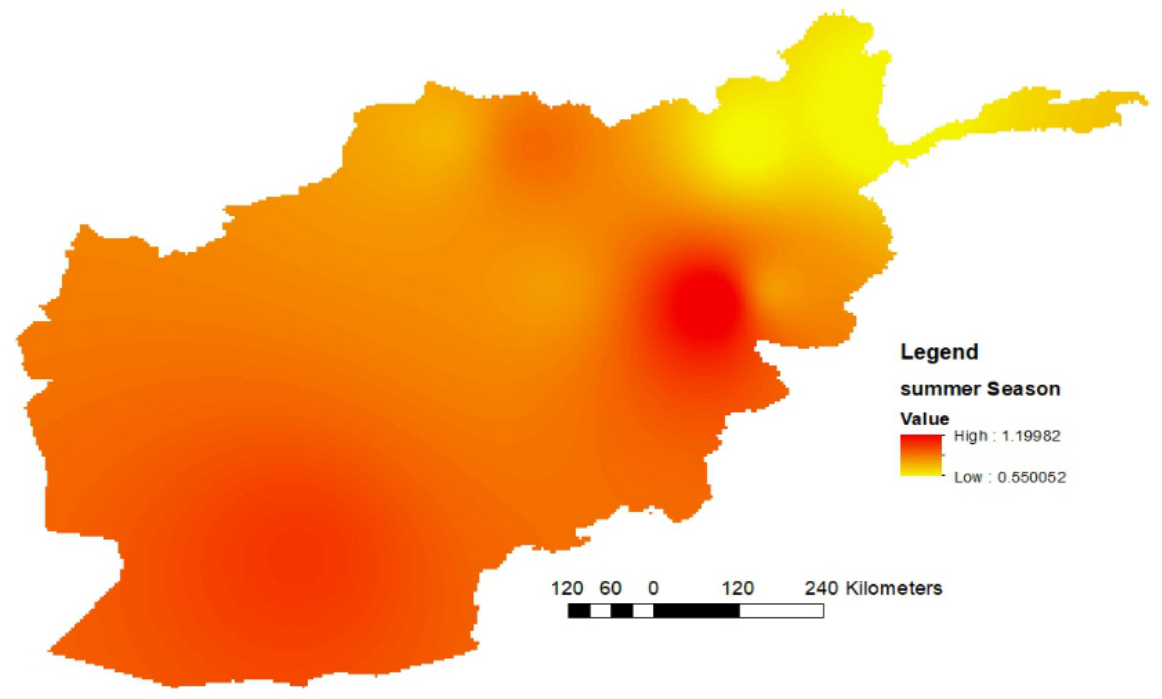

Fig. 3 Afghanistan Temperature variation in summer seasons, 2007-2017 years 


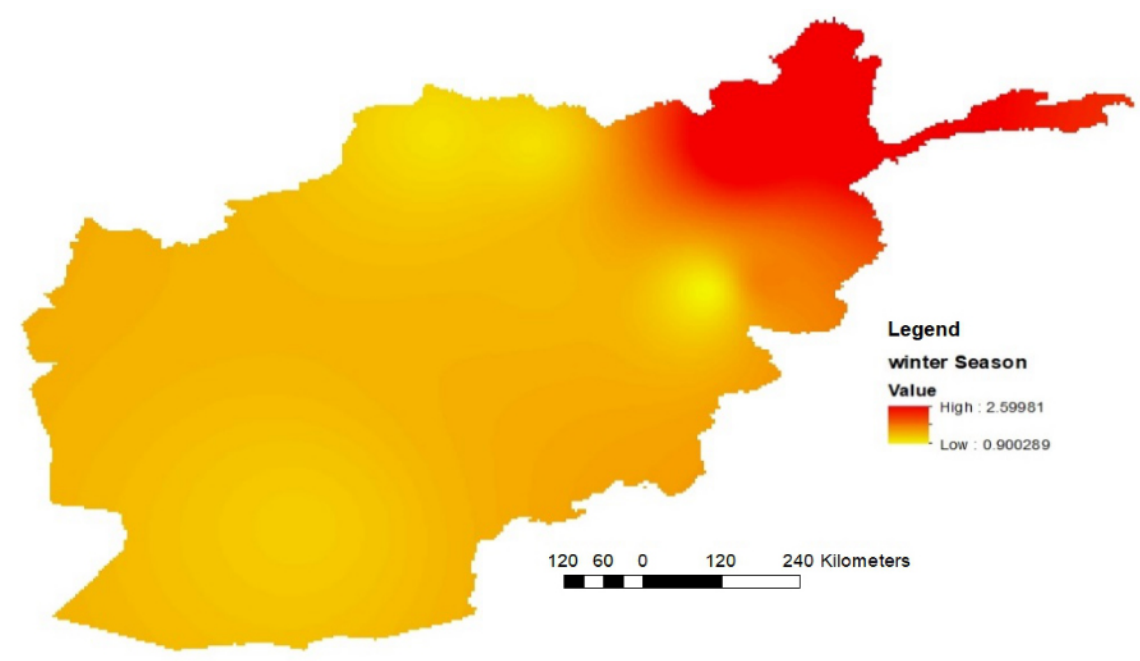

Fig. 4 Afghanistan Temperature variation in winter seasons, 2007-2017 years

During the summer seasons the temperature increased throughout the country gradually, but the most significant changes were in the center and south part of Afghanistan (Figure 3). The temperature increase during the winter season occurred mostly in the northeast part of Afghanistan, where most of glaciers are located (Figure 4). The temperature changes are also presented in the trend line graphs. For the summer season, the trend line is shown in Figure 5 and for the winter season the trend line is shown in Figure 6. Both trend lines indicate the increase of temperature for winter and summer seasons; however, the trend line for the winter season is steeper compared to the summer season.

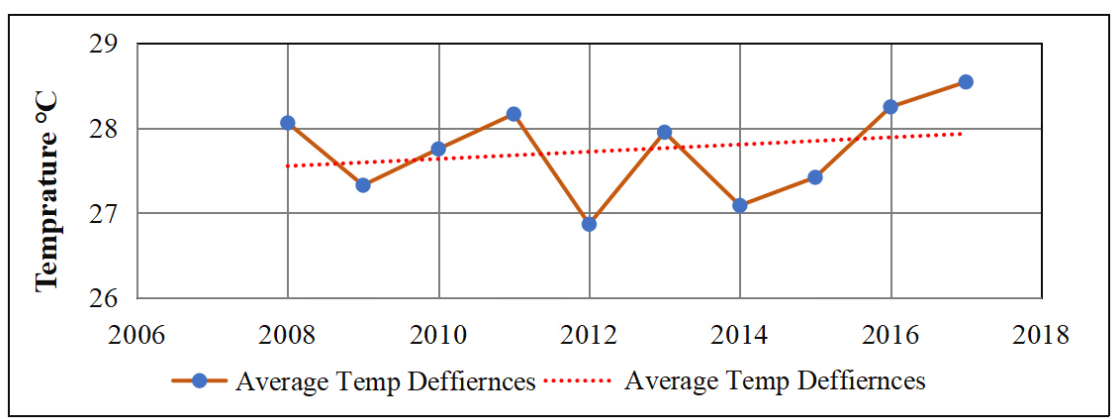

Fig. 5 Afghanistan temperature changes trend from 2007 to 2017 in summer

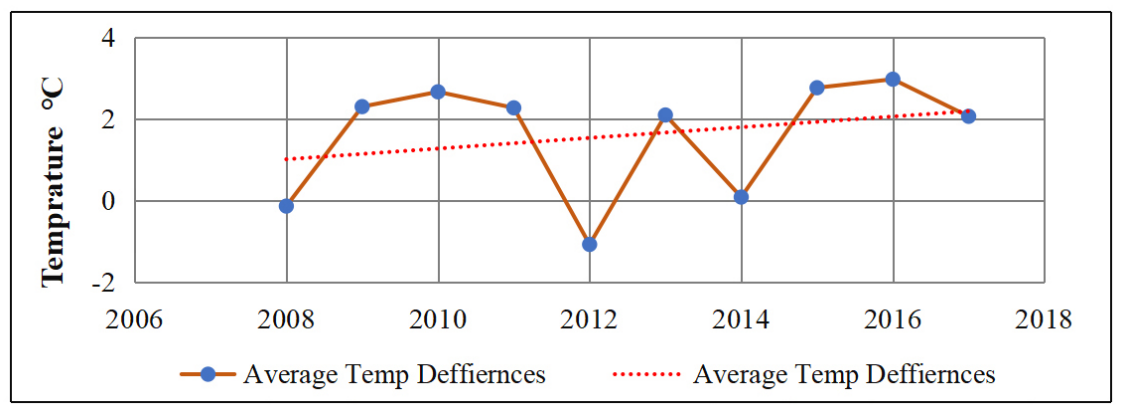

Fig. 6 Afghanistan temperature changes trend from 2007 to 2017 in winter

The field survey from Helmand (southern province), Kabul (center province) and Badakhshan (northeast province) has indicated that local people have been experiencing hotter summers and warmer winters compare to the past. The variation of monthly temperatures from 1901 to 2015 by the climate research unit (CRU) studies of the University of East Anglia (UEA) indicates an increase of about $1.03^{\circ} \mathrm{C}$, with the average monthly difference between the maximum 
and minimum temperature at approximately $3.66^{\circ} \mathrm{C}[25]$. The future projection of temperature was also analyzed by the different agencies which operate in Afghanistan. The UN climate change report, which presented in year 2016, shows that by the end of this century with one of the scenarios (RCP 4.5) the temperature in Afghanistan will increase by $1.4^{\circ} \mathrm{C}$ and with another scenario (RCP 8.2) the temperature may increase up to $6^{\circ} \mathrm{C}$.

\subsection{Precipitation}

Similar to temperature, precipitation is one of the sensitive climate change parameters. Based on IPCC reports, climate change will significantly influence precipitation distributions. The dry periods are getting even dryer, droughts are getting more devastating, wet period are becoming wetter, floods are getting powerful with the shift in the precipitation time, and precipitation intensity has increased with changes in the pattern - they are shorter, but much stronger. For all five river basins of Afghanistan, the changes trend lines are shown in Figure 7. The gauging station data from the years 2007 to 2017 were applied. For all the river basins of Afghanistan, the precipitations have decreased during the ten years. The Helmand river basin has the lowest precipitation. Next, with higher precipitations, the Hurrirod Murghab river basin, Panj Amo river basin, and the Kabul river basin. The Hurirod Murghab river basin has the biggest decrease in precipitation, as shown on the trend line.

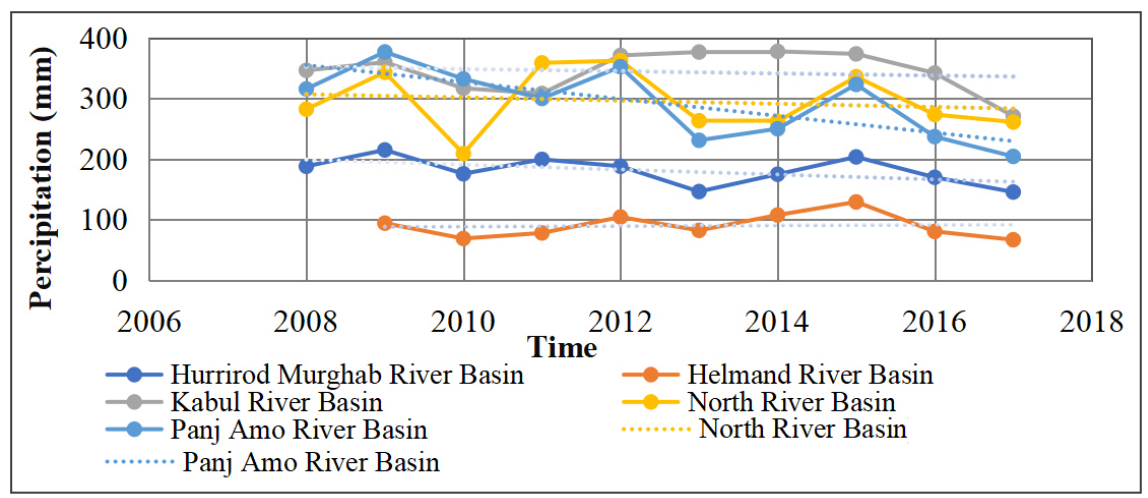

Fig. 7 Precipitation change in all Afghanistan river basins

The average precipitation trend line for the all five river basins in Afghanistan is shown in Figure 8.

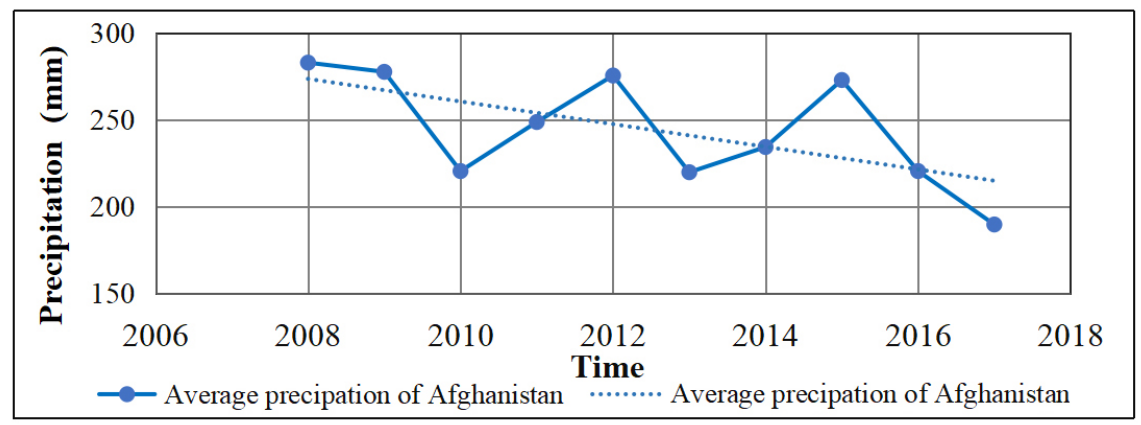

Fig. 8 Average precipitation change across Afghanistan

We provided interviews and during interviews; farmers and residents of Afghanistan mentioned that previously the whole country of Afghanistan had experienced a large amount of precipitation, with a bigger amount of snow from the middle of November to March. The local people emphasized that snow volume was up to several meters. Since most of the people are dependent on agriculture and natural resources, the snow plays a vital role in providing a continuous water supply to the streams. Recently, Afghanistan is experiencing a drier climate, which has a cold winter and warm summer with no or very little participation. Before, more snow was accumulated in winter and provided more melted water during the summer time. Moreover, snow seems to be melting faster than before [26].

\subsection{Glaciers}

Glaciers are an important source of fresh water as their melting maintains stream flow [27]. A glacier's mass balance 
is estimated by repeated mapping either by ground-based surveys or remote sensing [28]. In this study, the glacier changes were observed through the remote sensing techniques. Glacier volumes depend on the width, slope, side drag and mass balance scaling changes. Differences in the volume-area scaling of glaciers can be as a result of changes in those specified parameters and are most likely due to changing climate [29]. Observation shows that the volume of glaciers in the Wakhan corridor has decreased and the valley's lake size has increased [20]. Glaciers are mostly located in the northeastern part of Afghanistan and studies in the Wakhan corridor suggest that many glaciers have retreated; the frequency and size of pro glacial and valley-basin lakes have increased [20]. Afghanistan has many reserves of glaciers as an essential and valuable natural resource, but due to climate change it has reported a decrease in their numbers and volume. In this research, the glaciers of Afghanistan, which are located mostly in the central and northeast part of the country in the Hindukush Pamir Mountains, have been studied. The study is based on the ICIMOD data mapping of the glaciers using on the remote sensing techniques.

\subsubsection{Glaciers Distribution}

Satellite observation using the satellite map for the year 2015 indicates that Afghanistan glaciers are located in eight provinces including Badakhshan, Takhar, Panjsher, Nuristan, Baghlan, Bamyan, Parwan and Wardak in Figure 9. It indicates the distribution of current glaciers in Afghanistan in two main river basins (Kabul and Panj Amo). Most glaciers are located in the northeast part of the country especially in the Wakhan corridor and Badakhshan province. Following the Badakhshan province, the numbers decrease from Panjsher, Nuristan, Baghlan, Parwan, Bamyan and Wardak respectively. Besides, glacier distribution vs. elevation from 1990 to 2015 in a comparative manner is shown in Figure 10. It indicates that most of the glaciers are aggregated in the middle elevations of $4000-6000 \mathrm{~m}$. This analysis indicates that the glacier distribution has slowly decreased as the temperatures have increased and the decrease will likely continue.

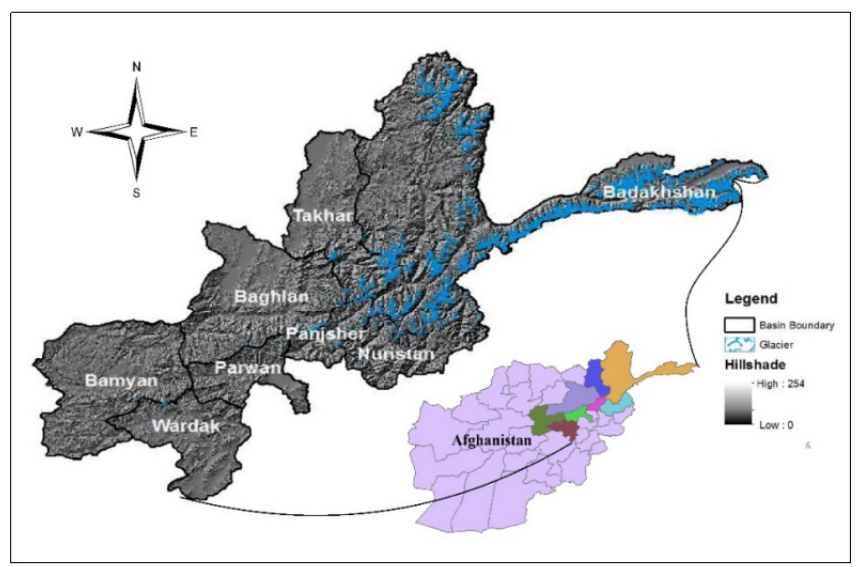

Fig. 9 Province based glacier distribution

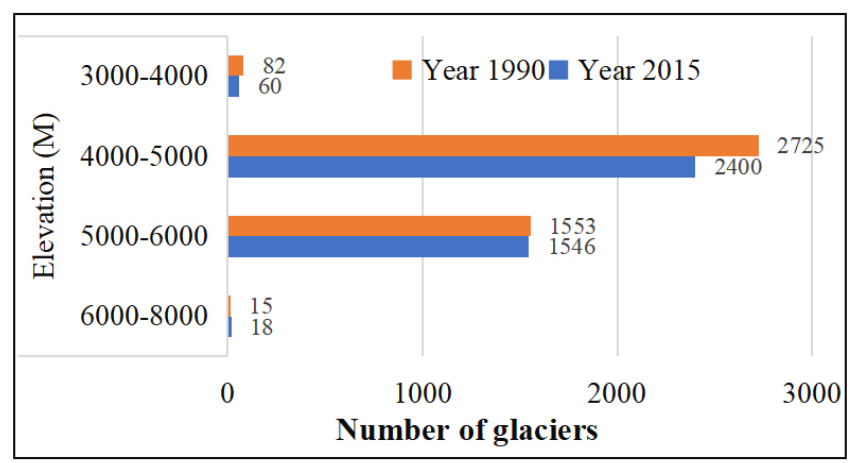

Fig. 10 Afghanistan glaciers and elevations from 1990 to 2015

Future projections and studies of the Indus river and Amu River basin indicate an increase of summer temperatures up to $5^{\circ} \mathrm{C}$ by 2099 . This will have a significant impact on melting of glaciers [30, 31]

\subsubsection{Glacier changes}


Glacier changes are recognized as an important indicator of climate change since they provide nearly $40 \%$ of stream flow, so changes of the glacier features directly impact the stream flow [32]. The changes of glaciers between 1990 and 2015 were analyzed for the Kabul and Panj Amu river basins, where most of the glaciers are located. The changes in glacier volume are the difference in glacier surface elevations over the glacier area multiplied by the average density of the removed or added material - giving the change in glacier mass [28]. Observation from the years 1990 to 2015 was conducted in these two basins using the remote sensing techniques. The number of glaciers has decreased. The retreat of glaciers has measured based on the changes in the number of glaciers, total glacier size (km2) and total ice reserve (m3) for each individual basin. Figure 11 illustrates the decreasing trends in the glacial features changes in the Kabul river basin. Similarly, Figure 12 indicates that similar to the Kabul river basin, the total number of glaciers, total glacial area and total ice reserve have decreased in the Punj Amu river basin.

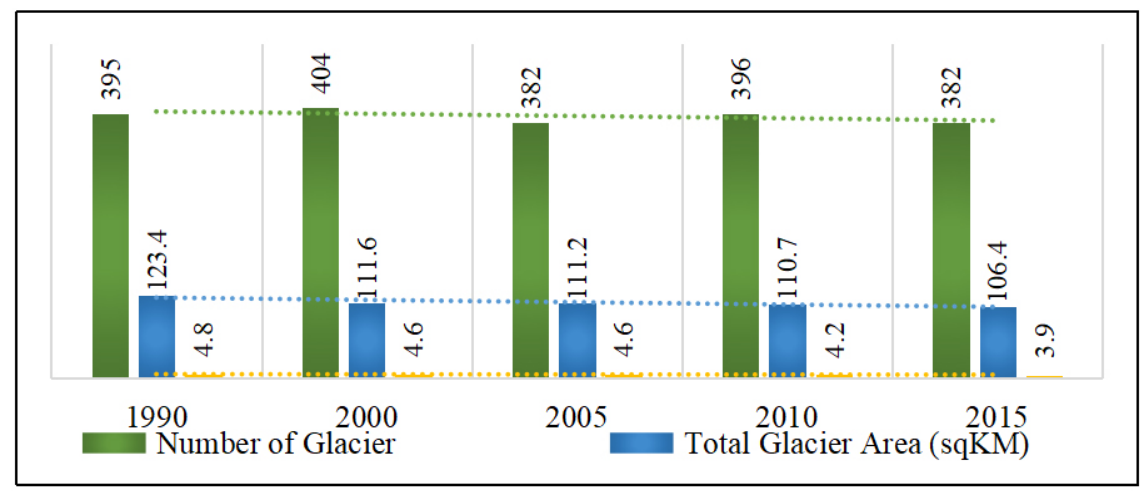

Fig. 11 Glacier changes in the Kabul river basin

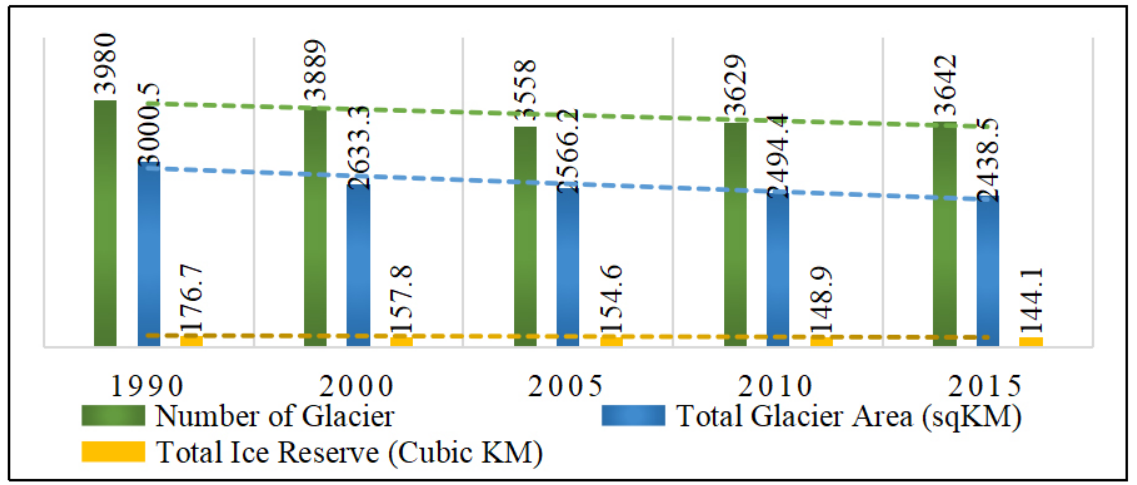

Fig. 12 Glacier changes over Punj Amu river basin

Furthermore, for the entire country, averages have been recorded for the changes in the glaciers (Figure 13). Figure 13 indicates that the number of glaciers, total glacier area, and total ice reserve has a decreasing trend in study's time period from 1990 to 2015.

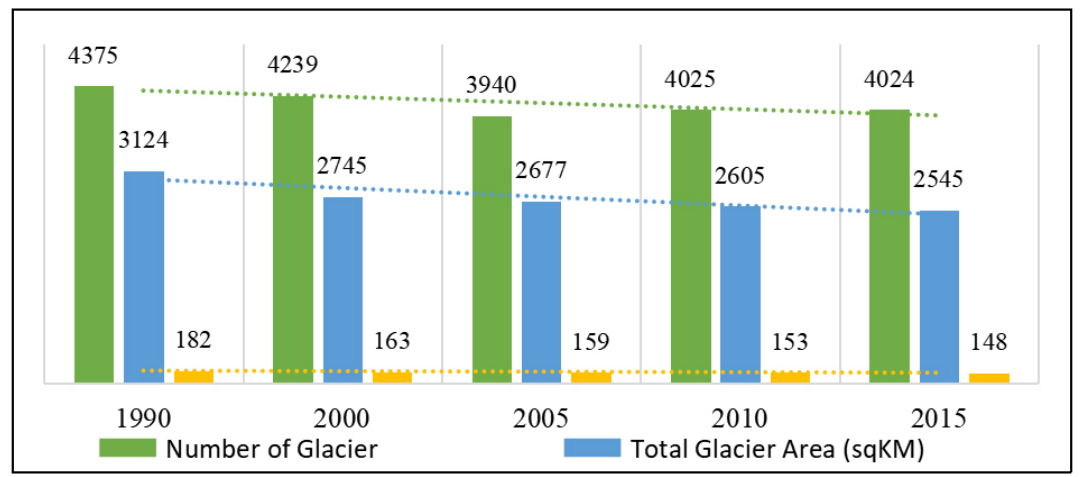

Fig. 13 Changes of glaciers throughout Afghanistan from 1990-2015 
Furthermore, in order to present the changes more clearly in percentages, we classified the overall 25 years (1990 to 2015) into four time periods (1990-2000, 2000-2005, 2005-2010, 2010-2015). Table 1 indicates that the period of 1990 to 2000 recorded the maximum percentage of retreat (12.13\%) although other periods show a decrease closer to $2.5 \%$. Overall, the analysis shows that from the year 1990 to 2015 the glacial area decreased by almost $18.5 \%$ in Afghanistan.

Table 1 Glacier change from 1990 to 2015 in Afghanistan

\begin{tabular}{|l|l|l|l|l|l|}
\hline Time & $\mathbf{1 9 9 0 - 2 0 0 0}$ & $\mathbf{2 0 0 0 - 2 0 0 5}$ & $\mathbf{2 0 0 5 - 2 0 1 0}$ & $\mathbf{2 0 1 0 - 2 0 1 5}$ & $\mathbf{1 9 9 0 - 2 0 1 5}$ \\
\hline Area & 379.118 & 67.42 & 72.211 & 60.212 & 578.961 \\
\hline Percentage & $-12.13 \%$ & $-2.46 \%$ & $-2.69 \%$ & $-2.31 \%$ & $18.53 \%$ \\
\hline
\end{tabular}

\subsection{Groundwater}

Groundwater is the main sources of drinking water in Afghanistan. Households, farmers and industries have been using this source for multiple purposes for centuries. Currently, this vital source is groundwater. The groundwater levels are depleted in all areas within all cities and have much polluted. Kabul city drinking water is entirely dependent on groundwater. Water companies also extract a large amount of groundwater to produce drinking bottled water. Moreover, the natural precipitation recharges system for the groundwater aquifers have been distorted by intensive urbanization in the main cities of Afghanistan. Moreover, climate change may influence water resources. Climate change with its resulting decrease of precipitation instantly could affect the surface and connected groundwater resources. Unfortunately, groundwater studies are limited in Afghanistan. For this paper, the changes in groundwater and springs are based on previous research works and recent data from the available wells database of Kabul city.

The Kabul river basin and groundwater resources are critical for the large region of Afghanistan. Groundwater levels in some urban areas in Kabul city region declined from 2004 to 2007. However, in the Logar province, an area near Kabul, the groundwater level increased. The drop in Kabul city groundwater levels is very related to the increase of the withdrawals by the growing population, mainly people migrating to the Kabul city region from other areas of Afghanistan, including Logar. Figure 14 presents data based on a study conducted by the USGS research team [33].

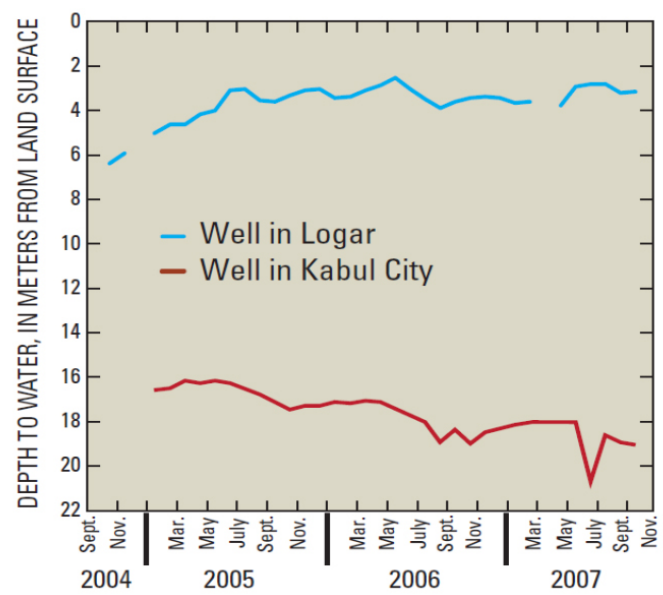

Fig. 14 Groundwater levels in two wells in the Kabul Basin, 2004-2007, Source: [33]

Similarly, another research study in a different area of the Kabul river basin, one in Kabul city and the other in the north part of Kabul at Shamali district, shows two different groundwater trends (Figure 15). Figure 15 indicates the Kabul city groundwater is decreasing, but in the northern part of Kabul, there is an increasing trend [34].

Furthermore, this study retrieved the groundwater wells data from the Ministry of Mines and Petroleum for the period of 2006 to 2018 (Figure 16). It shows a decreasing trend of the groundwater level with a mean rate of $3.8 \mathrm{~m} / \mathrm{year}$, and it indicates a 23m groundwater depletion from 2006 to 2018.

Due to climate change, a $10 \%$ reduction in recharge was simulated on groundwater resources in the Kabul river basin. This simulation showed that the resulting groundwater level declines could cause about one-quarter of all existing 
shallow supply wells to become inoperable or dry. As a result, in the headwater areas of the Paghman and Upper Kabul and Shomali sub-basins, more than $50 \%$ of the shallow supply wells could become inoperable [33].

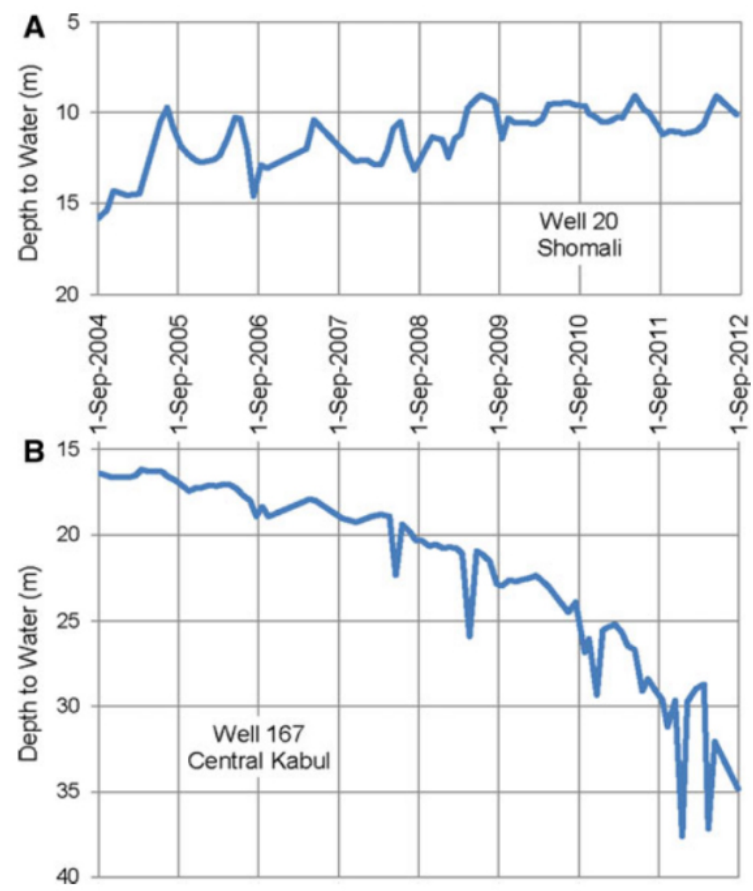

Fig. 15 Monthly depth to water at Afghanistan Geological Survey wells a 20 and b 167 from September 2004 to 2012 in the Kabul Basin, Afghanistan Source: [34]

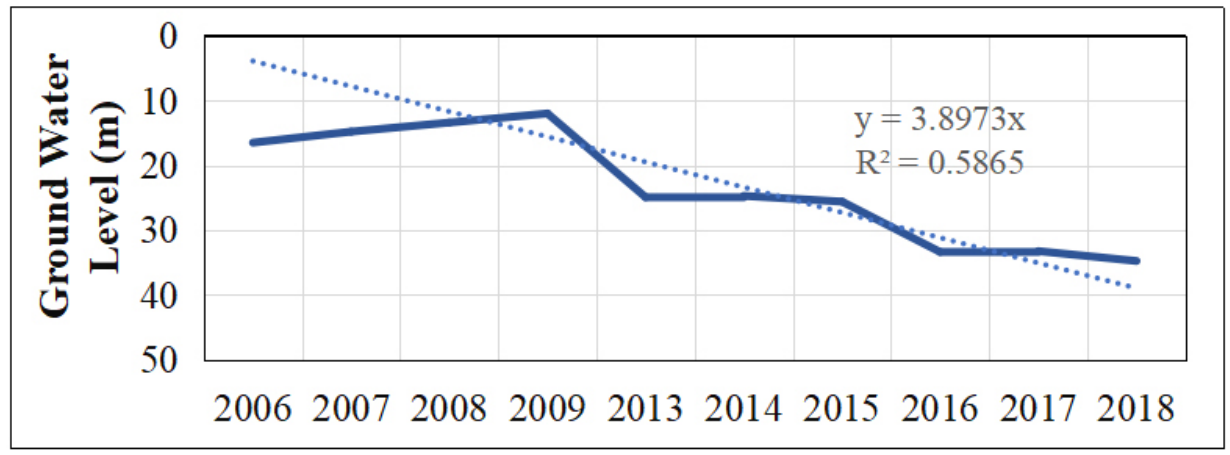

Fig. 16 Groundwater table trend in Kabul City (2008-2018)

Farmers all over Afghanistan have built and managed karezes for centuries using indigenous knowledge for utilizing the groundwater. Karez (ancient water supply systems in Afghanistan) is mainly used for irrigation systems and drinking water. It is a series of vertical wells that are dug into the shallow groundwater. An underground horizontal tunnel then connects these wells with an appropriate slope, which brings the groundwater eventually to an open irrigation canal [35]. Since 1980 in Afghanistan, the total acreage under irrigation has dropped in half and by 2008 some 60 to 70 percent of the karez were not in use, out of order, dried-up or with only low discharge due to drought conditions in recent years, low precipitation and consequently low groundwater discharge can be considered a result of many factors, including climate change [36].In the Helmand river basin, nearly half of Karez have gone dry and flows in operating karezes have also declined drastically (on average by $75 \%$ in Helmand Province). The main causes are a prolonged reduction in precipitation and an increased groundwater abstraction [37]. The karez network was depleted because of lower snow cover with less precipitation. Potentially, as a result of climate change since 1998 many karezes have been abandoned. Besides, 60 to $70 \%$ of the Karezes and $85 \%$ of the shallow wells are completely dry and the observed water levels are falling 0.5-3 meters per month [38]. 


\subsection{Runoff}

Climate change is affecting the stream flow, which has resulted in the bigger fluctuations, intensive devastating floods in the short term, and droughts during the long term. The five river basins of Afghanistan were analyzed for their volume changes for 55 years, 1962-2017 years, and the results are shown in Figure 17. The average stream flow changes for the five river basins are presented in Figure 18.

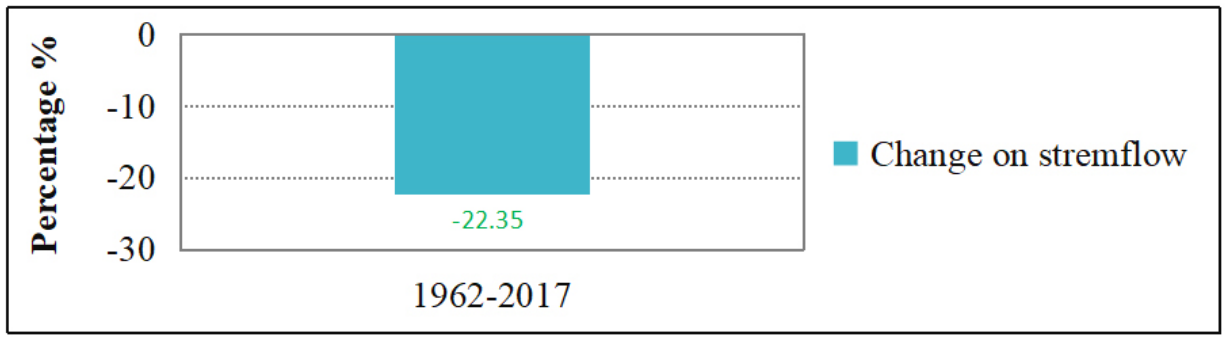

Fig. 17 Afghanistan river basins stream flow average volume changes from 1962 to 2017

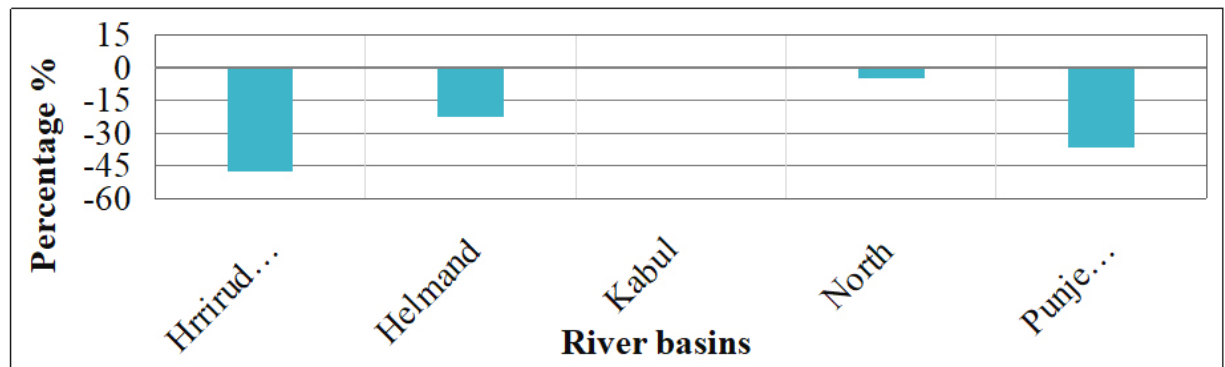

Fig. 18 Stream flow average difference of Afghanistan from year 1962 to 2017

The river basins average stream flow is also compared between year 1970s and 2010s. The result for Kabul river basin is shown in Figure 19 and 20 in two gauging stations (Asmar and Tangi-Saidan). Asmar is the trans-boundary gage station with Pakistan. Consequently, for river basins the hydrographs data were compared (Figure 21, 22,23,24 and 25).

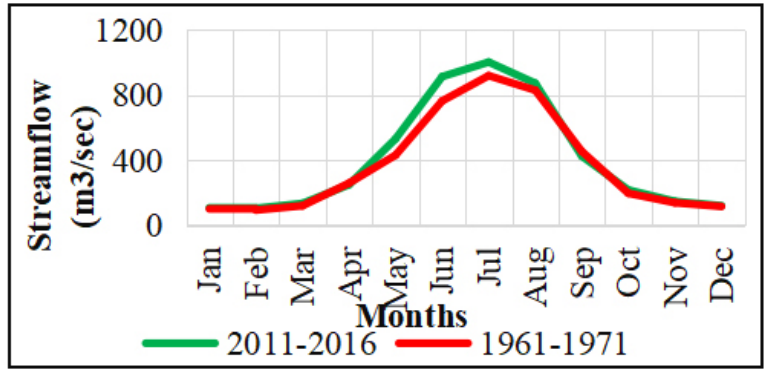

Fig. 19 Streamflow changes in Kabul River Basin (Asmar station)

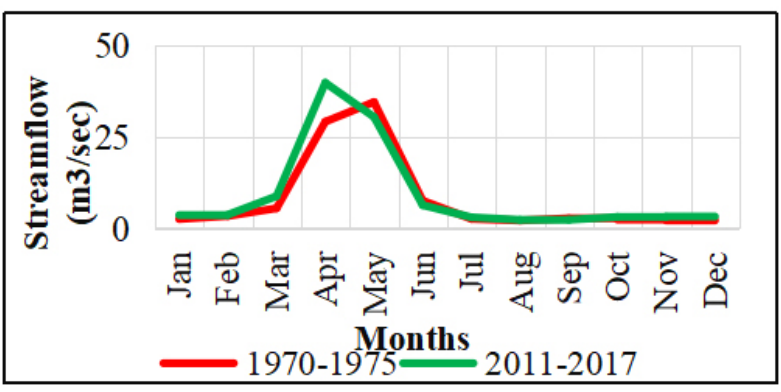

Fig. 21 Streamflow changes Helmand River Basin (Waras station)

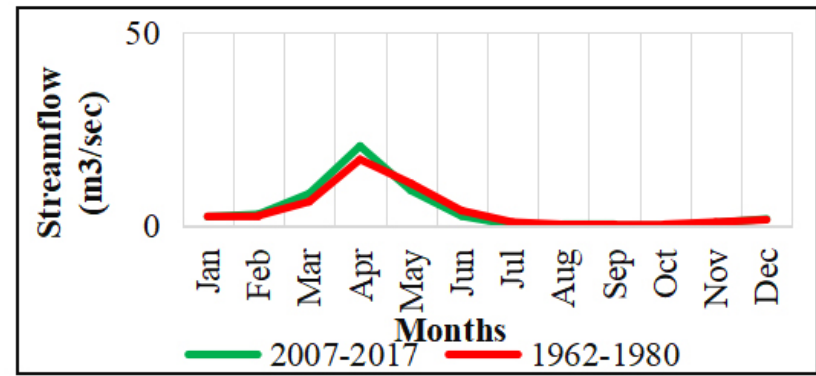

Fig. 20 Streamflow changes in Kabul River Basin (Tang-i-Saidan station)

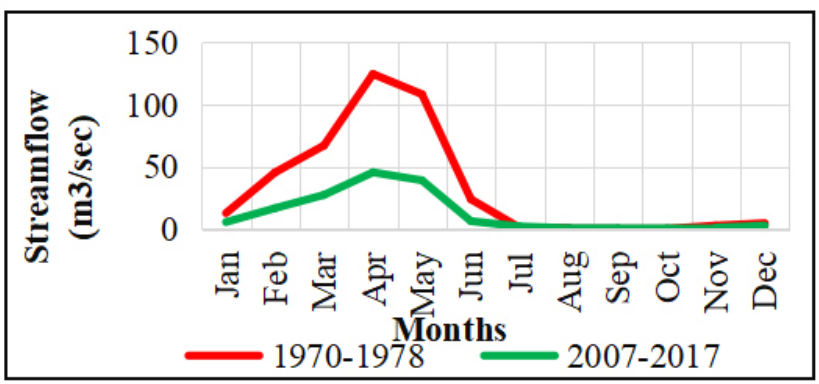

Fig. 22 Streamflow changes Hrirud-Murghab River Basin (Tirpul station) 


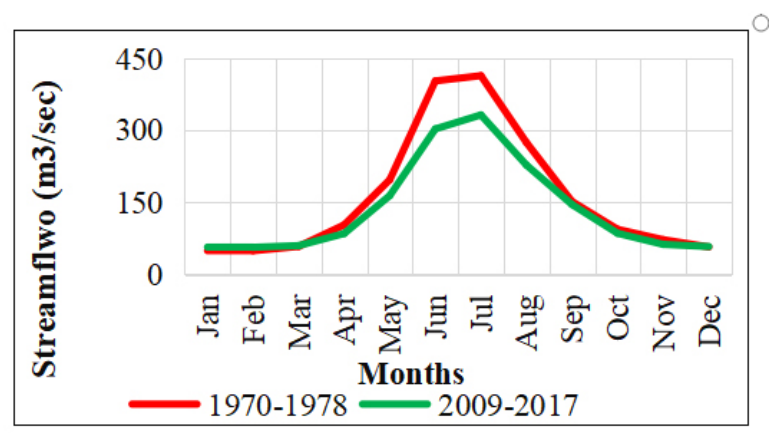

Fig. 23 Streamflow changes Panje Amu River Basin (Near Keshm station)

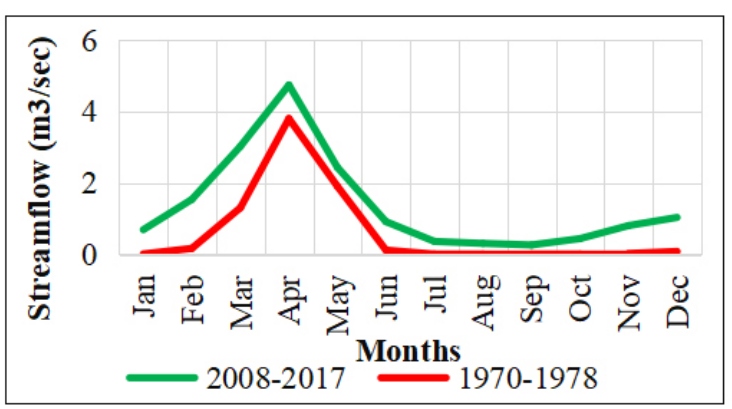

Fig. 24 Streamflow changes North River Basin (Qaisar station)

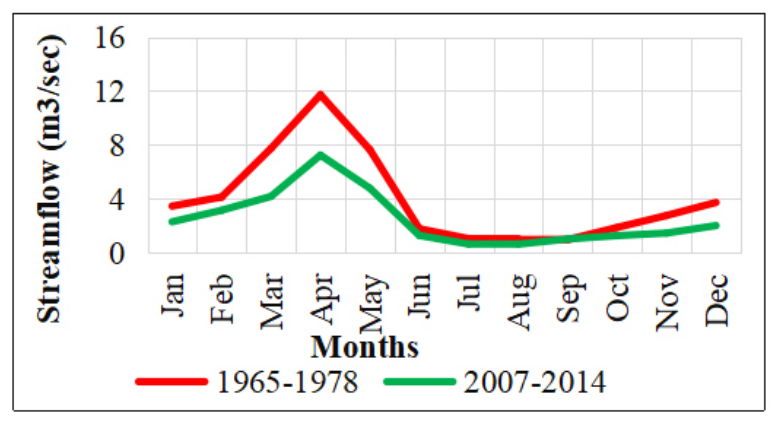

Fig. 25 Streamflow changes North River Basin (Pata Baba)

The change in the peak is happening when the glaciers and snow are melting earlier due to an increase in temperature. This is often combined with intensive rains, and thus causes the flash floods. In the Helmand river basin, it illustrated that due to climate change effects, the time of the hydrograph peak has shifted from May to April.

\subsection{Adaptation measures}

Adaptation has emerged as an essential area of research among climate change scientists in response to the call for preventing the damage [39]. IPCC (2001) defined adaptation measures is as an adjustment in ecological, social or economic systems in response to observed or expected changes in climatic stimuli in order to alleviate the adverse impact of change or take advantage of new opportunities [40]. Adaption options are impacted by the effectiveness of the actions such as the physical flood defenses in reducing the inundation, unknown future, uncertainties of scenarios and raising opportunities for some areas versus increasing pressure in other areas like flood embankment, which poses a threat for downstream residents. Risk appraisal is a psychological factor [39] that can potentially influence people's intentions. Various adaptation measures exist which in general demand reduction as an adaption option that can be implemented in different sectors [40], especially in the industrial sector to reduce their water consumption.

Climate change mostly brings floods, so structures along the river are mostly in danger. For flood adaption, Grothmann and Patt [39] suggest informing oneself about self-protection, avoiding using expensive furnishing in the basement and the first floor, purchasing flood protection devices like protective barriers for windows and door or pumps and taking structural measures. Structural measures include step-by-step levee erection [41] and broader restoration of alluvial, various gullies and wetlands [42]. In the agriculture sector, the agroforestry practices that are crucial for the adaptation process include tree based adaption options and methods to characterize variation in farming systems [43]. Moving from cropping to pasture land use for sheep [44] is a long term adaptation strategy that needs to be considered. Crops are the most vulnerable resources under climate change because they require proper attention. These adaption strategies involve adjusting sowing dates, increasing the soil nutrients and changing the cultivars [45]. Optimization of the water management systems [46] can be done through improving the drip irrigation system, enhancing the groundwater recharging system, increasing the knowledge of water resources, expanding the spate-irrigated agriculture, and developing the productive soil and water conservation system [47]. Rain infrastructure adaptation [48] is necessary to improve food security and the public health of the target population through irrigated agricultural production and clean water conveyance [47]. Increasing the capacity of some reservoirs to the maximum limit and managing the aquifer 
recharge (MAR) by artificial recharge system to put excess surface water in the ground for infiltration to aquifers can result in an increase of the groundwater resources availability [49].

\section{Discussion}

Understanding the changes of historical water resources and climate factors of Afghanistan is necessary for different water users, scientific communities and decision makers. The study of climate change needs long temporal data nearly 30 years, but due to many years of war in Afghanistan, observed information is missing. Therefore, this study was based on an analysis of the limited available data which cannot reflect all scenario of the Past. Overall temperature in Afghanistan for last ten years has an increasing trend that compare to changes in daily temperature in central and south Asia, an increase in the percentage of warm nights/days and decreases in the percentage of cold nights/days for the period 1961-2000 has been shown [50]. Furthermore, the projection of temperature until 2099 indicates an increase of temperature by $6.4^{\circ} \mathrm{C}[51]$ temperature, precipitation and five additional climate indices for extremes and agriculture assessments (heavy precipitation; spring precipitation; growing season length (GSL for all of Afghanistan. Although uncertainty exists in the future, it is reasonable to claim that the hard evidence shows the temperature is increasing.

The precipitation results indicate a decreasing trend over all of Afghanistan in the last decade from 2008 to 2017 and especially in the Hurrirod Murghab and Panj Amo river basins. Regarding the historic base of precipitation during field visits in different places of the country, the older residents have indicated that the amount of precipitation has decreased tremendously. The projection of climate change for Central South Asia, particularly for Afghanistan, indicates a nominal decreasing trend from 2006 to 2099 [52]. Similarly, the projection of precipitation for Central Asia, including Afghanistan, suggests a decrease in precipitation by the end of this century [53]. The projected seasonal precipitation temperature for the Kabul River basin showed both a downtrend and an upward trend in spring and summer, but the overall annual precipitation pattern is predicted to decrease $(-2.18 \%)$ by the end of this century [54] although climate change is an uncertain phenomenon which needs a more detailed study on a river basin scale.

The decrease of glaciers from 1994 to 2015 is assumed due to increase of temperature. The glaciers data is relying on the satellite data although the field visits is not conducted but residence in remote area are confirmed the decrease on glaciers. Many people in the mountain areas depend on melt water, so water stress makes this region vulnerable to drought [55]. There is a lack of proper research on the groundwater in Afghanistan and some studies have only concentrated in big cities, such as Kabul. The general problems in the big cities are urbanization and the over-extraction of groundwater. The result found from this study shows decreasing on the groundwater mainly due to urbanization rather than climate change. Because the focus of this study is mainly on main cities where increasing the population is a major contribution in consuming of groundwater.

Reduction in the average runoff in all river basins in this study has noticed, but the time of the peak has not changed, except for the Helmand River basin. In comparison of some pervious studies confirms that volume was reduced by $20 \%$ in the Amu Darya River basin [56]. For the Kabul River basin, the projected runoff data indicates a discharge variation and the occurrence of extreme floods and drought events [18]which, together with snow and glacier melt, produce intense floods. The Kabul river basin originates from the Hindukush Mountains and is frequently hit by such floods. We analyses flood frequency and intensity in Kabul basin for a contemporary period (1981-2015. Due to uncertainty in the climate change, the status of flow for the future is not certain, but overall changes in the pattern of stream flow in more intensive droughts and floods can be expected.

From the analysis of the stream flow data, the overall volume of water has decreased much from 1962 to 2007. Through comparing all the river basins, Figure 17 shows the river basin water volume of the Hurrirud Murghab river has been reduced by $48 \%$ and the Puje Amo by $36 \%$. Efforts to address the climate change effects in Afghanistan through strategic adaption needs to be increased [48]surveys have suggested that only a minority of firms conducts strategic adaptations, which we define as anticipatory and target-oriented action with the purpose of increasing resilience to climate change. While several barrier-centered studies have investigated the causality of non-adaptation in industry, the examined barriers are often not problem-specific. Furthermore, it has been shown that even in cases when managers perceive no barriers to adaptation at all, strategic adaptations may still not be conducted. On this background, the present analysis focuses on the logic of adaptive inaction, which we conceive, in particular, as inaction with regard to strategic adaptations. Adopting an action-theoretical perspective, the study examines (a with government enforcement of climate adaptation policies and the increased participation of local stakeholders [57]. The adaptation measures mentioned in this study are very general and require further analysis and application at the local level. 


\section{Conclusion}

The results of this study indicate that Afghanistan water resources have gradually become threatened through climate change and anthropogenic distortions. In general, due to climate change, the water resources are decreasing, and the devastating phenomena of droughts and floods are expected. Data has shown that the temperature for winters throughout one decade increased from $0.9^{\circ} \mathrm{C}$ to $2.5^{\circ} \mathrm{C}$ and in the summers from $0.5{ }^{\circ} \mathrm{C}$ to $1.2{ }^{\circ} \mathrm{C}$, which shows winter is getting warmer compared to summer. The increase in temperature during summers is concentrated in the Northeast and during winter in the central and southeast part of Afghanistan. Future temperatures are projected to increase by $6{ }^{\circ} \mathrm{C}$ by the end of this century. Precipitation results for the one decade indicated a very rapid decrease, especially in the Hurrirod Murghab and Panj Amo river basins. The projection of precipitation for the Kabul and Helmand River basins indicate a flood and drought status by the end of 2099, but overall the country shows a decrease in precipitation. Studies on glaciers demonstrate the volume of the glaciers have been reduced by $18.53 \%$ between 1994 and 2015 . The historical stream flow data from 1962 to 2017 indicates that the overall country surface water volume has been reduced by $22 \%$, particularly in the Hurrirod Murghab river basin by $48 \%$, Punj Amo by $38 \%$, Helmand by $22 \%$, North by $4 \%$ and Kabul river basin shows slightly increased by $0.3 \%$. Besides, the stream flow peak has decreased in all the river basins of Afghanistan, but in the Helmand river basin, the peak of average discharge shifted earlier. The future projections of stream flow indicate sharpness in the peak of the hydrograph, which predicts more flooding and drought situations.

\section{References}

[1] S. Vicuna and J. A. Dracup, "The evolution of climate change impact studies on hydrology and water resources in California," Clim. Change, vol. 82, no. 3-4, pp. 327-350, 2007.

[2] H. Middelkoop et al., "Impact of Climate Change on Hydrological Regimes and Water Resource Management in the Rhine River Basin," Clim. Change, vol. 49, pp. 105-128, 2001.

[3] IPCC, "Lobet et al. 2011," Cambridge Univesity Press, 2007.

[4] K. C. Abbaspour, M. Faramarzi, S. S. Ghasemi, and H. Yang, "Assessing the impact of climate change on water resources in Iran," Water Resour. Res., vol. 45, no. 10, Oct. 2009.

[5] WFP, UNEP, and NEPA, "Climate Change in Afghanistan," 2016.

[6] K. D. Frederick and D. C. Major, "Climate Change and Water Resources," Clim. Change, vol. 37, no. 1, pp. 7-23, 1997.

[7] P.-S. Yu, T.-C. Yang, and C.-K. Wu, "Impact of climate change on water resources in southern Taiwan," J. Hydrol., vol. 260, no. 1-4, pp. 161-175, Mar. 2002.

[8] S. Piao et al., "The impacts of climate change on water resources and agriculture in China," Nature, vol. 467, no. 7311, pp. 43-51, Sep. 2010.

[9] E. Lioubimtseva and G. M. Henebry, "Climate and environmental change in arid Central Asia: Impacts, vulnerability, and adaptations," J. Arid Environ., vol. 73, no. 11, pp. 963-977, 2009.

[10] M. M. Q. Mirza, "Climate change, flooding in South Asia and implications," Reg. Environ. Chang., vol. 11, no. SUPPL. 1, pp. 95-107, 2011.

[11] V. Thomas, "Climate Change in Afghanistan: Perspectives and opportunities," Kabul, 2016.

[12] J. F. Shroder, "Afghanistan Water and Climate Change," Nat. Resour. Afghanistan, pp. 504-522, 2014.

[13] H. B. Dulal, "Cities in Asia: how are they adapting to climate change?," J. Environ. Stud. Sci., vol. 9, no. 1, pp. 13-24, 2019.

[14] J. Lie, H. Duan, and D. Chen, "An Evaluation Model for The Impact of Climate Change on Regional Instability," in MATEC Web of Conferences, 2018, vol. 175, pp. 1-7.

[15] H. Wang, "Impact of climate change on national vulnerability," IOP Conf. Ser. Earth Environ. Sci., vol. 208, pp. 1-5, 2018.

[16] S. Jolly and N. Ahmad, Climate Refugees in South Asia. 2019.

[17] T. M. Lee, E. M. Markowitz, P. D. Howe, C. Ko, and A. A. Leiserowitz, "risk perception around the world," Nature, pp. 1-7, 2015. 
[18] N. Hofstra, M. Iqbal, E. Querner, Z. Dahri, and A. Khan, "Impact of Climate Change on Flood Frequency and Intensity in the Kabul River Basin," Geosciences, vol. 8, no. 4, p. 114, 2018.

[19] A. Mohanty, M. Hussain, M. Mishra, D. B. Kattel, and I. Pal, "Exploring Community Resilience and Early Warning Solution for Flash Floods, Debris flow and Landslides in conflict prone villages of Badakhshan, Afghanistan," Int. J. Disaster Risk Reduct., 2018.

[20] U. K. Haritashya, M. P. Bishop, J. F. Shroder, A. B. G. Bush, and H. N. N. Bulley, "Space-based assessment of glacier fluctuations in the Wakhan Pamir, Afghanistan," Clim. Change, vol. 94, no. 1-2, pp. 5-18, 2009.

[21] O. Najmuddin, X. Deng, and R. Bhattacharya, "The dynamics of land use/cover and the statistical assessment of cropland change drivers in the Kabul River Basin, Afghanistan," Sustain., vol. 10, no. 2, pp. 1-18, 2018.

[22] M. Ghulami, "Assessment of climate change impacts on water resources and agriculture in data-scarce Kabul basin , Masoud Ghulami To cite this version : HAL Id : tel-01737052," no. December 2017, 2018.

[23] J. D. Farrington and J. Li, Climate Change Impacts on Snow Leopard Range. Elsevier Inc., 2016.

[24] R. K. Mall, R. K. Srivastava, and T. Banerjee, "Disaster Risk Reduction Including Climate Change Adaptation Over South Asia : Challenges and Ways Forward," Int. J. Disaster Risk Sci., 2018.

[25] A. Boudjella, "Modelling Afghanistan 's Average Monthly Temperature from 1901 to 2015," Asia Proc. Soc. Sci., vol. 1, no. 3, pp. 61-66, 2018.

[26] M. N. Nasimi, "Investigation of Climate Change Impact Using Water Balance Model for Water Infrastructures \& Adaptation Development in Maidan-Kabul River Basin, Afghanistan,” Kabul Polytehnic University, 2019.

[27] K. Stahl, R. D. Moore, J. M. Shea, D. Hutchinson, and A. J. Cannon, "Coupled modelling of glacier and streamflow response to future climate scenarios," Water Resour. Res., vol. 44, no. 2, pp. 1-13, 2008.

[28] V. Radić and R. Hock, "Glaciers in the Earth's Hydrological Cycle: Assessments of Glacier Mass and Runoff Changes on Global and Regional Scales," Surv. Geophys., vol. 35, no. 3, pp. 813-837, 2014.

[29] B. Bahr, F. Meier, and S. D. Peckham, "The physical basis of glacier volume-area scaling perturbations in the ice mass balance rate D ( rate of ice accumulation area at relatively high elevations low elevations ( D 0 on a yearly average ), Volume-Size," J. Geophys. Res., vol. 102, no. B9, pp. 20355-20362, 1997.

[30] A. F. Lutz, H. W. ter Maat, H. Biemans, A. B. Shrestha, P. Wester, and W. W. Immerzeel, "Selecting representative climate models for climate change impact studies: an advanced envelope-based selection approach," Int. J. Climatol., vol. 36, no. 12, pp. 3988-4005, 2016.

[31] A. F. Lutz, W. W. Immerzeel, P. D. A. Kraaijenbrink, A. B. Shrestha, and M. F. P. Bierkens, "Climate change impacts on the upper indus hydrology: Sources, shifts and extremes," PLoS One, vol. 11, no. 11, pp. 1-33, 2016.

[32] T. Bolch, Past and Future Glacier Changes in the Indus River Basin. Zurich, Switzerland: Elsevier Inc., 2019.

[33] M. . Mack, T. . Chornak, L. . Coplen, M. . Plummer, Rezai, and I. . Verstraeten, "Availability of Water in the Kabul Basin, Afghanistan,” Kabul, 2010.

[34] T. J. Mack, M. P. Chornack, and M. R. Taher, "Groundwater-level trends and implications for sustainable water use in the Kabul Basin, Afghanistan," Environ. Syst. Decis., vol. 33, no. 3, pp. 457-467, 2013.

[35] M. J. Khan, G. Pacha, M. Shahzad Khattak, and R. Oad, "Water distribution of traditional karez irrigation systems in Afghanistan," Irrig. Drain., vol. 64, no. 2, pp. 169-179, 2015.

[36] D. B. Williams, "Finding water in the heart of darkness: Afghanistan's ongoing water challenges | EARTH Magazine," 2010. [Online]. Available: https://www.earthmagazine.org/article/finding-water-heart-darknessafghanistans-ongoing-water-challenges. [Accessed: 10-Feb-2020].

[37] B. J. M. Goes, U. N. Parajuli, M. Haq, and R. B. Wardlaw, "Karez (qanat) irrigation in the Helmand River Basin, Afghanistan: a vanishing indigenous legacyL'irrigation Karez (qanat) dans le Bassin de la Rivière Helmand en Afghanistan: un héritage indigène en voie de disparitionRiego por Karez (qanat) en la cuenca, "Hydrogeol. J., vol. 25, no. 2, pp. 269-286, 2016.

[38] G. L. Macpherson, W. C. Johnson, and H. Liu, "Viability of karezes ( ancient water supply systems in Afghanistan) in a changing world," Appl. Water Sci., 2015. 
[39] T. Grothmann and A. Patt, "Adaptive capacity and human cognition: The process of individual adaptation to climate change," Glob. Environ. Chang., vol. 15, no. 3, pp. 199-213, 2005.

[40] W. N. Adger, N. W. Arnell, and E. L. Tompkins, "Successful adaptation to climate change across scales," Glob. Environ. Chang., vol. 15, no. 2, pp. 77-86, 2005.

[41] D. Serre, B. Barroca, and Y. Diab, "Urban flood mitigation: Sustainable options," WIT Trans. Ecol. Environ., vol. 129, pp. 299-309, 2010.

[42] N. Favretto, A. J. Dougill, L. C. Stringer, S. Afionis, and C. H. Quinn, "Links between climate change mitigation, adaptation and development in land policy and ecosystem restoration projects: Lessons from South Africa," Sustain., vol. 10, no. 3, 2018.

[43] L. Kmoch, T. Pagella, M. Palm, and F. Sinclair, "Using Local Agroecological Knowledge in Climate Change Adaptation: A Study of Tree-Based Options in Northern Morocco," Sustainability, vol. 10, no. 10, p. 3719, 2018.

[44] G. Robinson et al., "Adapting to Climate Change: Lessons from Farmers and Peri-Urban Fringe Residents in South Australia," Environments, vol. 5, no. 3, p. 40, 2018.

[45] U. Akumaga, A. Tarhule, C. Piani, B. Traore, and A. A. Yusuf, "Utilizing Process-Based Modeling to Assess the Impact of Climate Change on Crop Yields and Adaptation Options in the Niger River Basin , West Africa," Agronomy, vol. 8, no. 11, pp. 1-19, 2018.

[46] Z. Zhou, L. Qu, and T. Zou, "Quantitative analysis of urban pluvial llood alleviation by open surface water systems in New Towns: Comparing almere and Tianjin Eco-City," Sustain., vol. 7, no. 10, pp. 13378-13398, 2015.

[47] J. M. Nzuma, M. Waithaka, R. M. Mulwa, M. Kyotalimye, and G. Nelson, "Strategies for Adapting to Climate Change in Rural Sub-Saharan Africa A Review of Data Sources, Poverty Reduction Strategy Programs ( PRSPs ) and National Adaptation Plans for Agriculture (NAPAs ) in ASARECA Member Countries," IFPRI Discuss. Pap., vol. 1013, no. July, p. 64, 2010.

[48] U. Meinel and R. Schüle, "The difficulty of climate change adaptation in manufacturing firms: Developing an action-theoretical perspective on the causality of adaptive inaction," Sustain., vol. 10, no. 2, pp. 1-16, 2018.

[49] N. Guyennon, F. Salerno, I. Portoghese, and E. Romano, "Climate change adaptation in a Mediterranean semi-arid catchment: Testing Managed Aquifer Recharge and increased surface reservoir capacity," Water (Switzerland), vol. 9, no. 9, 2017.

[50] X. B. Sun et al., "Changes in extreme temperature events over the Hindu Kush Himalaya during 1961-2015," Adv. Clim. Chang. Res., vol. 8, no. 3, pp. 157-165, 2017.

[51] V. Aich et al., "Climate Change in Afghanistan Deduced from Reanalysis and Coordinated Regional Climate Downscaling Experiment (CORDEX)—South Asia Simulations," Climate, vol. 5, no. 2, p. 38, 2017.

[52] L. Das, J. Akhter, M. Dutta, and J. K. Meher, "Ensemble-based CMIP5 simulations of monsoon rainfall and temperature changes over South Asia," pp. 41-60, 2015.

[53] T. Ozturk, M. T. Turp, M. Türkeş, and M. L. Kurnaz, "Projected changes in temperature and precipitation climatology of Central Asia CORDEX Region 8 by using RegCM4.3.5," Atmos. Res., vol. 183, pp. 296-307, 2017.

[54] M. H. Hassanyar and J. Tsutsumi, "Multi-model Ensemble Climate Change Projection for Kabul River Basin, Afghanistan under Representative Concentration Pathways," Mod. Environ. Sci. Eng., vol. 03, no. 05, pp. 291$301,2017$.

[55] H. D. Pritchard, “Asia's glaciers are a regionally important buffer against drought," Nature, vol. 545, no. 7653, pp. 169-174, 2017.

[56] C. J. White, T. W. Tanton, and D. W. Rycroft, "The Impact of Climate Change on the Water Resources of the Amu Darya Basin in Central Asia," Water Resour. Manag., vol. 28, no. 15, pp. 5267-5281, 2014.

[57] M. Schermer et al., "The Role of Transdisciplinary Research for Agricultural Climate Change Adaptation Strategies," Agronomy, vol. 8, no. 11, p. 237, 2018. 